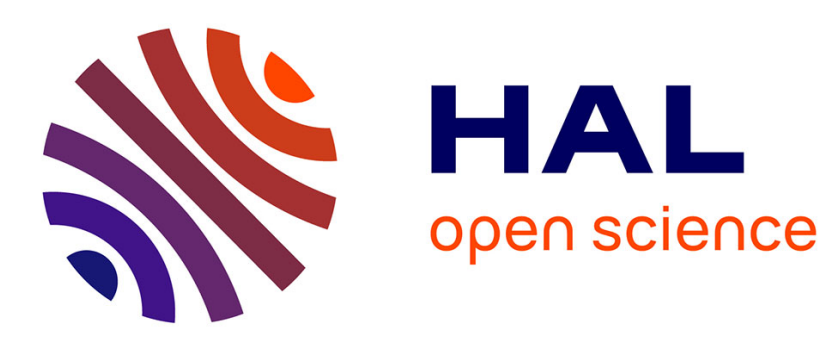

\title{
Quantitative prediction of genome-wide resource allocation in bacteria
}

Anne Goelzer, Vincent Fromion

\section{To cite this version:}

Anne Goelzer, Vincent Fromion. Quantitative prediction of genome-wide resource allocation in bacteria. FOSBE, Oct 2016, Magdebourg, Germany. pp.1. hal-01603637

\section{HAL Id: hal-01603637 \\ https://hal.science/hal-01603637}

Submitted on 5 Jun 2020

HAL is a multi-disciplinary open access archive for the deposit and dissemination of scientific research documents, whether they are published or not. The documents may come from teaching and research institutions in France or abroad, or from public or private research centers.
L'archive ouverte pluridisciplinaire HAL, est destinée au dépôt et à la diffusion de documents scientifiques de niveau recherche, publiés ou non, émanant des établissements d'enseignement et de recherche français ou étrangers, des laboratoires publics ou privés. 


\title{
Quantitative prediction of genome-wide resource allocation in bacteria
}

\author{
Anne Goelzer" and Vincent Fromion ${ }^{*}$ \\ *UR1404 MaIAGE, INRA, Université Paris-Saclay, F-78350 Jouy-en-Josas, France.
}

\section{INTRODUCTION}

Predicting resource allocation between cell processes is the primary step towards decoding the evolutionary constraints governing bacterial growth under various conditions (Scott et al, 2010). Quantitative prediction at genome-scale remains a computational challenge as current methods are limited by the tractability of the underlying problem (Molenaar et al, 2009) or by simplifying hypotheses.

\section{METHODS AND RESULTS}

In this talk, we present the constraint-based modeling method Resource Balance Analysis (RBA). By considering the bacterial cell as a self-replicating system, the RBA method intrinsically captures the bottleneck due to resource sharing between all biological processes as a non-smooth convex feasibility problem that is efficiently solved through the resolution of an equivalent Linear Programming (LP) optimization problem. The optimal cellular configuration can be computed under the objective of growth rate maximization by solving a sequence of LPs (Goelzer et al., 2009; Goelzer et al., 2011). The refinement of the underlying mathematical description of cell processes compared to well-established constraint-based methods like Flux Balance Analysis (Varma et al., 1994) entails inevitably an increased number of parameters in the model (Vasquez et al., 2008; Goelzer et al., 2011; O'Brien et al., 2013). By combining physiological and large-scale datasets (growth rate, fluxome, and absolute protein abundances), we successfully calibrated RBA for the Gram-positive model bacterium Bacillus subtilis and showed that RBA accurately predicts the resource allocation for a wide range of growth conditions (Goelzer et al., 2015). During the calibration process, the apparent catalytic rates of active metabolic enzymes are estimated and most of them are linearly decreasing with decreasing growth rate.

\section{DISCUSSION}

The regulation of most cellular processes is consistent with the objective of growth rate maximization except for a few suboptimal processes which likely integrate more complex objectives such as coping with stressful conditions and survival. We also illustrate how calibrated RBA enables the prediction of complex strategies like managing the uptake of nutrients (carbon and/or amino acid sources) in complex medium. Altogether, RBA offers new opportunities to investigate design principles in prokaryotes and to exploit them for future biotechnological applications.
Goelzer et al. (2009). Cell design in bacteria as a convex optimization problem. 48th IEEE Conference on Decision and Control, 4517-4522.

Goelzer et al. (2011). Cell design in bacteria as a convex optimization problem. Automatica, 47(6), 1210-1218.

O'Brien et al. (2013). Genome-scale models of metabolism and gene expression extend and refine growth phenotype prediction. Mol Syst Biol, 9, 693.

Molenaar et al. (2009). Shifts in growth strategies reflect tradeoffs in cellular economics. Mol Syst Biol, 5, 323.

Scott et al. (2010). Interdependence of cell growth and gene expression: origins and consequences. Science, 330, 1099-1102.

Varma et al. (1994). Stoichiometric flux balance models quantitatively predict growth and metabolic by-product secretion in wild-type Escherichia coli W3110. Appl Environ Microbiol, 60, 3724-3731.

Vasquez et al. (2008). Impact of the solvent capacity constraint on E. coli metabolism. BMC Syst Biol, 2, 7.

\section{REFERENCES}

